\title{
Systematic Review of Cervical Discography as a Diagnostic Test for Chronic Spinal Pain
}

Laxmaiah Manchikanti, MD1, Elmer E. Dunbar, MD², Bradley W. Wargo, DO', Rinoo V. Shah, MD', Richard Derby, MD', and Steven P. Cohen, MD ${ }^{5}$

From: ${ }^{1}$ Pain Management Center of Paducah, Paducah, KY; ${ }^{2}$ Pain Control Network PSC, Louisville, KY; ${ }^{3}$ Guthrie Clinic, Horseheads, NY; ${ }^{4}$ Spinal Diagnostics \& Treatment Center, Daly City, CA; and 5Johns Hopkins School of Medicine, Baltimore, MD.

Dr. Manchikanti is Medical Director of the Pain Management Center of Paducah, Paducah, KY, and Associate Clinical Professor of Anesthesiology and Perioperative Medicine, University of Louisville, Louisville, KY.

Dr. Dunbar is Medical Director of Pain Control Network, Louisville, KY.

Dr. Wargo is an Interventional Pain

Physician at the Pain Management

Center of Paducah, Paducah, KY.

Dr. Shah is in the Department of Anesthesiology, Guthrie Clinic, Horseheads, NY.

Dr. Derby is Medical Director of Spinal Diagnostics \& Treatment Center, Daly

City, CA, and Associate Professor, Department of Physical Medicine and Rehabilitation, Stanford University, Stanford, CA.

Dr. Cohen is Associate Professor, Department of Anesthesiology and Critical Care Medicine, Pain Management Division, Johns Hopkins

School of Medicine, Baltimore, MD, and Walter Reed Army Medical Center, Washington, DC.

Address correspondence: Laxmaiah Manchikanti, MD 2831 Lone Oak Road

Paducah, Kentucky 42003

E-mail:drlm@thepainmd.com

Disclaimer: There was no external funding in the preparation of this manuscript. Conflict of interest: None.

Manuscript received: $12 / 28 / 2008$ Revised manuscript received: 01/13/2009

Accepted for publication: 2/26/2009

Free full manuscript: www.painphysicianjournal.com
Background: Chronic neck pain represents a significant public health problem. Despite high prevalence rates, there is a lack of consensus regarding the causes or treatments for this condition. Based on controlled evaluations, the cervical intervertebral discs, facet joints, and atlantoaxial joints have all been implicated as pain generators. Cervical provocation discography, which includes disc stimulation and morphological evaluation, is often used to distinguish a painful disc from other potential sources of pain. Yet in the absence of validation and controlled outcome studies, the procedure remains mired in controversy.

Study Design: A systematic review of the cervical discography literature.

Objective: To evaluate the validity and usefulness of cervical provocation discography in managing and diagnosing discogenic pain by means of a systematic review.

Methods: Following a comprehensive search of the literature, selected studies were subjected to a modified Agency for Healthcare Research and Quality (AHRQ) diagnostic accuracy evaluation. Qualitative analysis was conducted using 5 levels of evidence, ranging from Level I to III with 3 subcategories in Level II. The rating scheme was modified to evaluate the diagnostic accuracy.

Results: A systematic review of the literature demonstrated that cervical discography plays a significant role in selecting surgical candidates and improving outcomes, despite concerns regarding the false-positive rate, lack of standardization, and assorted potential confounding factors. Based on the studies utilizing the International Association for the Study of Pain (IASP) criteria, the data show a prevalence rate ranging between $16 \%$ and $20 \%$. Based on the 3 studies that utilized IASP criteria during the performance of cervical discography, the evidence derived from studies evaluating the diagnostic validity of the procedure, the indicated level of evidence is Level II-2 based on modified U.S. Preventive Services Task Force (USPSTF) criteria.

Limitations: Limitations include a paucity of literature, poor methodologic quality, and very few studies performed utilizing IASP criteria.

Conclusion: Cervical discography performed according to the IASP criteria may be a useful tool for evaluating chronic cervical pain, without disc herniation or radiculitis. Based on a modified AHRQ accuracy evaluation and USPSTF level of evidence criteria, this systematic review indicates the strength of evidence as Level II-2 for diagnostic accuracy of cervical discography.

Key words: Neck pain, headache, cervical discogenic pain, cervical intervertebral disc, cervical provocation discography, false-positive rates, diagnostic accuracy, outcomes, cervical facet joint pain, controlled diagnostic blocks

Pain Physician 2009; 12:305-321 
ervical provocation discography, an imageguided procedure in which a contrast agent is injected into the nucleus pulposus of the intervertebral disc, includes disc stimulation and morphological assessment. It is intended to both identify a painful cervical intervertebral disc and depict internal derangements (1-4).

Over 50 years ago, Smith and Nichols $(5,6)$ emphasized pain reproduction as the principal feature of cervical discography. Cloward $(7,8)$ described 2 types of pain during cervical disc stimulation: pain arising from internal disc disruption (IDD) (i.e., discogenic pain) and neurogenic pain that stems from a herniated disc fragment causing nerve root or dural irritation. Cloward (9) stimulated cervical discs mechanically and electrically to verify that the evoked pain originated in the discs themselves, rather than from irritation of adjacent structures. Cloward also proposed that disc pain is mediated through sinuvertebral nerves, which in the cervical region are very small and undetectable by conventional dissection methods. However, subsequent anatomical studies did visually identify cervical sinuvertebral nerves and confirmed Cloward's (8) experimental observations and inferences (10-12). Intervertebral disc innervation in the cervical spine is analogous to that in the lumbar spine, with cervical discs receiving innervation posteriorly from the sinuvertebral nerves, laterally from the vertebral nerve, and anteriorly from the sympathetic trunks $(10,11)$.

In a report published in 1964, Holt (13) questioned the validity and role of cervical discography, citing a high false-positive rate in asymptomatic subjects. He based this assumption on the contention that fissures and pain provocation were normal features in people without neck pain. In an observational study, Klafta and Collis $(14,15)$ found that cervical discography was less accurate than myelography in predicting surgical findings. In 1988, Simmons et al (16) re-evaluated Holt's data (17) in the lumbar spine, finding the methodology so riddled with flaws as to render the findings irrelevant.

Studies conducted in cadavers and patients have re-examined Holt's conclusions $(18,19)$. These studies have established fissures to be normal age-related findings that do not necessarily indicate symptomatology, and that demonstrating them with discography is immaterial $(2,20)$. Thus, reproduction of a patient's typical pain is now considered to be the critical component of cervical discography (2). Supporting this assertion, Schellhas et al (18) found that pressurizing nor- mal discs failed to provoke pain in both symptomatic and asymptomatic patients, whereas abnormal discs tended to produce concordant pain. Roth (21) and Kofoed (22) proposed the concept of analgesic discography. During this time frame, cervical discography was increasingly used for surgical planning $(23,24)$. As the centerpiece of ongoing controversy, cervical discography has been reviewed in multiple publications (1-8, 13-15, 18-34).

Building on a foundation first established by Cloward $(7,8)$, Lotz and Ulrich (35) classified pain emanating from a degenerative disc into 2 distinct types: 1) radicular pain secondary to stenosis and/or nerve root irritation; and 2) predominantly axial pain due to IDD. They suggested that painful discs are characterized by a confluence of nerve in-growth, inflammation, and mechanical hypermobility. In addition, not only cervical intervertebral discs, but other structures such as zygapophysial joints, muscles, and ligaments, are potential sources of neck pain (5-12,19-22,25,26,30,36-48). Studies conducted using controlled diagnostic blocks have implicated the facet joints in between $36 \%$ to $67 \%$ of patients with chronic neck pain (41-48). Discography studies have also been characterized by wide variations in epidemiology, with reported prevalence rates ranging between $16 \%$ and $41 \%(31,32)$. Numerous investigations have found pain referral maps for cervical discogenic pain to be indistinguishable from those for facetogenic pain $(2,18,25,30,39,47)$. Since pain radiation patterns are more closely related to level than structure, and advanced imaging modalities are incapable of discerning nonspecific from nociceptive degeneration, a pivotal question arises about how best to correlate symptoms with pathology.

The major obstacle confronting proponents of cervical discography is the lack of consensus as to what constitutes a positive response. Widespread variations in criteria exist not only for pain provocation (i.e., designation of concordance and threshold for a positive response), but also for morphological classification. Whereas some investigators have interpreted certain patterns of contrast dispersion as being indicative of disc pathology, others have found a lack of correlation between morphology and pain reproduction $(1-4,15,27,28,33,34,49)$.

Imaging studies such as radiographs, myelography, computed tomography (CT), CT-myelography, and magnetic resonance imaging (MRI) are incapable of identifying a degenerated disc as painful $(4,18,28,33,34,50-55)$. Consequently, the referral pat- 
terns can only be used to suggest which segment(s) is most likely to be the source of pain and, therefore, the levels in which the investigation should focus (2).

Multiple questions have been raised regarding the utility of cervical discography, including the high reported false-positive rate in select subpopulations; the lack of standardization; the discrepancies regarding the need for "control levels," pain concordance, and pain intensity threshold; and utilization (1-4,33,34,5565). However, in a recent systematic review of lumbar provocation discography conducted by Wolfer et al (58), the authors re-analyzed the published data on false-positive rates using the International Association for the Study of Pain (IASP) criteria. They found the false-positive rate in subjects without co-existing psychopathology and prior surgery to be very low, and indicated that Level II-2 evidence supported lumbar discography as a diagnostic tool (66).

Shah et al (33) provided an extensive systematic and narrative review of discography as a diagnostic test for spinal pain; however, they included evaluation of all spinal regions. They provided systematic assessment evaluating the diagnostic accuracy of discography with inclusion of criteria of the modern practice of discography, along with quality assessment criteria utilizing AHRQ and the quality assessment tool for diagnostic accuracy studies (QUADAS) criteria $(67,68)$. They reviewed 9 studies evaluating the accuracy of cervical discography and concluded that there was moderate evidence supporting the role of discography in identifying a subset of patients with cervical discogenic pain. Shah et al (33) extensively discussed various assumptions, caveats, analogies, and convictions of discogenic pain. They called for future research that investigates the precise mechanism of how discography induces pain and how this correlates with functional activities. Further, they also called for external validation - not based on subjective pain assessments - of the ability of discography to precisely identify the disc as the pain generator.

Thus, this systematic review is undertaken to evaluate the accuracy of cervical provocation discography in the diagnosis of discogenic pain.

\section{Methods}

\section{Literature Search}

A literature search was conducted from 1966 to December 2008 using multiple sources including the MEDLINE and EMBASE databases, the Cochrane li- brary, systematic and narrative reviews, NIH Clinical Trials Registry, and bibliographic references published in the English language. The search terminology included the terms cervical disc, cervical discogenic pain, cervical provocation discography, and cervical analgesic discography.

\section{Inclusion Criteria}

Included in the analysis was any study that clearly reported discography findings in asymptomatic volunteers or symptomatic patients with cervical pain greater than 3 months duration. Studies in asymptomatic patients were not included in the accuracy analysis. Since the key elements of discography are pain provocation and imaging of the intervertebral disc, we specifically searched for contingency tables or data that compared pain provocation to intervertebral disc imaging.

Discography, whether alone or in combination with other diagnostic tests, should be described clearly. At a minimum, pain provocation, disc morphology, and a controlled disc evaluation should be reported. Further, the study should report that the discography was performed in accordance with modern principles utilizing fluoroscopy, pain provocation, and control disc as per IASP criteria $(1,2)$.

Exclusion criteria included abstracts, publications in non-peer reviewed journals, technical reports, expert opinions, general review articles, and single case reports. Further, the studies including patients with ethical barriers and patients with chronic spinal pain due to disc protrusion or verifiable non-discogenic etiology were also excluded.

\section{Review Methods}

\section{Study Selection}

Studies were selected if they met the inclusion criteria utilizing IASP criteria with provocation discography with control discs and involving patients with chronic pain of at least 3 months duration.

\section{Data Extraction}

Relevant data on methodology and outcomes were collected.

\section{Methodologic Quality Assessment}

The Agency for Healthcare Research and Quality (AHRQ) criteria for diagnostic testing (67) were used for methodologic quality assessment. Based on the 
Table 1. Modified quality of evidence developed by USPSTF.

\begin{tabular}{|l|l||}
\hline I: & Evidence obtained from multiple properly conducted diagnostic accuracy studies. \\
\hline II-1: & Evidence obtained from at least one properly conducted diagnostic accuracy study of adequate size. \\
\hline II-2: & Evidence obtained from at least one properly designed small diagnostic accuracy study. \\
\hline II-3: & Evidence obtained from diagnostic studies of uncertainty. \\
\hline III: & Opinions of respected authorities, based on clinical experience descriptive studies and case reports or reports of expert committees. \\
\hline \hline
\end{tabular}

Adapted and modified from the U.S. Preventive Services Task Force (USPSTF) (66).

weighted scoring system of AHRQ criteria (67) developed by the guidelines committee of the American Society of Interventional Pain Physicians (ASIPP), up to 100 total points can be awarded for each study. These criteria have been revised and also have been utilized in other publications $(60,69-75)$. Only studies scoring 50 or above were used in the analysis. Each study was scored independently by 2 reviewers. Any discrepancies or conflicts were arbitrated by a third reviewer to either reach a consensus agreement or break a tie. If there was a conflict of interest with the reviewed manuscripts with authorship or any other type of conflict, the involved authors did not review the manuscripts for quality assessment or evidence synthesis.

\section{Qualitative Analysis of Evidence}

Qualitative analysis was conducted using 5 levels of evidence, ranging from Level I to III with 3 subcategories in Level II, as illustrated in Table 1 (66). Since the levels were designed to classify evidence for efficacy based on clinical outcome studies, the rating scheme was modified to evaluate diagnostic accuracy (68-77).

\section{Results}

\section{Literature Search}

Figure 1 illustrates search results. The search yielded 658 articles with abstracts reviewed. Of these, 2 systematic reviews and 110 manuscripts were reviewed.

\section{Methodologic Quality Assessment}

Literature search showed a total of 33 studies evaluating either diagnosis or outcome of cervical discography (13-15, 18-21,23-26,30-32,49,50,54-56,78-91). However, only 3 studies utilized provocation discography with 2 control discs $(31,32,83)$. These studies met inclusion criteria, thus they were evaluated for methodological quality and scoring. Among the other studies, 3 studies (13-15) had poor methodological quality of disc provocation, 2 were cadaveric studies $(78,89)$, one study performed the procedure intraoperatively (23), 8 manuscripts evaluated surgical outcomes rather than diagnostic validity $(24,56,79,80,82,87)$, one study (25) evaluated provocative cervical discography symptom mapping, and another study evaluated symptom provocation of fluoroscopically guided cervical nerve roots (91).

The methodologic quality assessment criteria was 60 of 100 for the 3 studies assessed $(31,32,83)$.

\section{Controlled Discography Study Characteristics}

Three studies met methodologic quality assessment criteria $(31,32,83)$ as shown in Table 2.

Bogduk and Aprill (31) determined the prevalence of discogenic pain in 56 patients with post-traumatic neck pain that underwent provocation discography. Utilizing IASP criteria requiring 2 negative control discs, $20 \%$ of the patients had positive discograms.

This study evaluated all patients with discography and medial branch blocks. The percentage of patients with both positive discograms and facet blocks raise doubts concerning the study design and reliability of disc provocation. Only a single medial branch block was employed in this study, and prior investigations have reported the false-positive rate for uncontrolled zygapophysial joint blocks to range between $27 \%$ and $63 \%(42,44,48,92)$.

Yin and Bogduk (32) conducted a retrospective study designed to determine the prevalence of different causes of neck pain in a private practice pain clinic. Among the $46 \%(n=143)$ of patients who completed all investigations, the prevalence of zygapophysial joint pain was $55 \%$, discogenic pain $16 \%$, lateral atlanto-axial joint pain $9 \%$, and radiculopathy $3 \%$. A definitive diagnosis remained elusive in $32 \%$ of those patients who completed investigations. However, in those subjects who completed controlled blocks or more than one invasive test, a pathoanatomic diagnosis was obtained in 


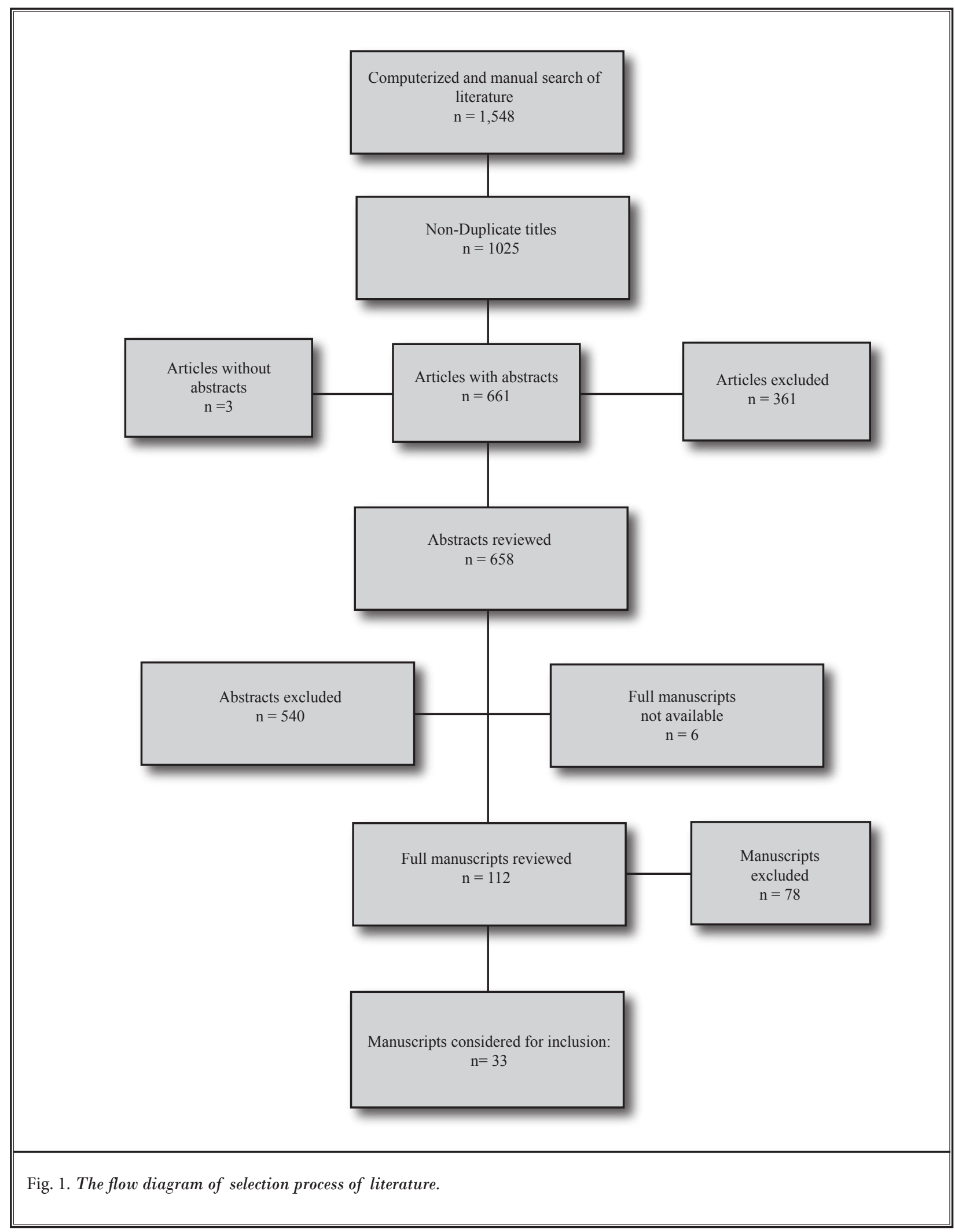


Pain Physician: March/April 2009:12:305-321

Table 2. Methodologic quality evaluation and scoring of cervical discography studies.

\begin{tabular}{|c|c|c|c|c|c|c|c|c|}
\hline \multirow[b]{3}{*}{ STUDY } & 1 & 2 & & & & & 5 & TOTAL \\
\hline & \multirow[b]{2}{*}{$\begin{array}{c}\text { Study } \\
\text { Population } \\
(15)\end{array}$} & \multirow[b]{2}{*}{$\begin{array}{c}\text { Adequate } \\
\text { Description } \\
\text { of Test } \\
(10)\end{array}$} & \multicolumn{2}{|c|}{$\begin{array}{c}\text { Appropriate Reference Standard } \\
(30)\end{array}$} & \multicolumn{2}{|c|}{$\begin{array}{l}\text { Blinded Comparison of Test } \\
\text { (30) }\end{array}$} & \multirow[b]{2}{*}{$\begin{array}{c}\text { Avoidance } \\
\text { of } \\
\text { Verification } \\
\text { Bias } \\
\text { (15) }\end{array}$} & \multirow[b]{2}{*}{$(100)$} \\
\hline & & & $\begin{array}{l}\text { Appropriate } \\
\text { reference } \\
\text { standard (gold } \\
\text { standard) } \\
\text { used for } \\
\text { comparison } \\
\text { (15) }\end{array}$ & $\begin{array}{c}\text { Reference } \\
\text { standard } \\
\text { reproducible } \\
(15)\end{array}$ & $\begin{array}{c}\text { Evaluation of } \\
\text { test without } \\
\text { knowledge of } \\
\text { disease status, } \\
\text { if possible } \\
\text { (15) }\end{array}$ & $\begin{array}{l}\text { Independent, } \\
\text { blind } \\
\text { interpretation } \\
\text { of test and } \\
\text { reference } \\
(15)\end{array}$ & & \\
\hline $\begin{array}{l}\text { Palit et al } 1999 \\
\text { (83) }\end{array}$ & 10 & 10 & 10 & 10 & 15 & -- & 15 & 60 \\
\hline $\begin{array}{l}\text { Bogduk and Aprill } \\
1993(31)\end{array}$ & 10 & 10 & 10 & 10 & 15 & -- & 15 & 60 \\
\hline $\begin{array}{l}\text { Yin and Bogduk } \\
2008(32)\end{array}$ & 10 & 10 & 10 & 10 & 15 & -- & 15 & 60 \\
\hline
\end{tabular}

( ) weighted item score

Methodological criteria and scoring adapted from West S et al. Systems to Rate the Strength of Scientific Evidence, Evidence Report, Technology Assessment No. 47. AHRQ Publication No. E016 (67).

$83 \%$ of subjects. The advantages of this study include a comprehensive evaluation for all causes of neck pain and the large number of subjects. The flaws include the retrospective study design and high percentage of patients who did not complete all investigations, specifically, one-third was due to reimbursement issues.

Palit et al (83) prospectively evaluated cervical discectomy and fusion outcomes in 38 patients with chronic neck pain without signs of radiculopathy or myelopathy. All subjects had positive radiological imaging and discography utilizing IASP standards requiring 2 adjacent controlled discs. Seventeen patients had painful degenerative discs without other structural abnormalities.

\section{Characteristics of Outcome Studies}

The validity of a diagnostic test can be determined by evaluating treatment outcomes. Multiple studies have been published assessing the predictive value of cervical discogenic pain prior to anterior cervical interbody fusion. These findings must be examined in the context of lack of standardization, evolution of both discography and surgical treatment, and lack of evidence supporting arthrodesis for degenerative spondylosis (93-100). Deyo et al (93) concluded that the evidence supporting cervical fusion to treat discogenic pain is weak and conflicting. In a Cochrane review, Jacobs et al (94) determined that discectomy alone provides com- parable symptomatic relief to fusion, yet is associated with shorter recuperation times and hospital stays.

The limitations of published outcome studies include methodological flaws: lack of prospective studies comparing outcomes between cohorts who were screened with preoperative discography and those who were not, publication bias, and wide variability in outcome measures and follow-up periods.

Yet despite these limitations, Cohen and Hurly (57) described that when all data are assembled, a pattern emerges whereby higher success rates tend to be reported when discography is used as a screening tool before cervical fusion than when surgery is based solely on imaging and clinical findings. Even then, only one study by Palit et al (83) utilized controlled provocation discography. Thus, the results of these evaluations must be considered with caution.

The characteristics of discography studies reporting surgical outcomes are reported in Table 3.

Of the total 17 studies evaluating surgical outcomes based on cervical discography $(14,21,23,24,50,54-$ $56,79-83,85-88)$, one study (83) was performed utilizing IASP criteria, with 13 studies reporting positive results $(21,24,50,54-56,79-83,86,87)$ and 4 studies reporting negative results $(14,23,85,88)$. Further, 12 studies were conducted in the pre-MRI era $(14,21,23,24,56,79-82,86$ 88 ) and 5 studies were done when MRI was widely available $(50,54,55,83,85)$.

Among the post-MRI positive reports, Palit et al 
Table 3. Characteristics of surgical outcomes.

\begin{tabular}{|c|c|c|c|c|c|}
\hline Study & $\begin{array}{l}\text { Study } \\
\text { Design }\end{array}$ & Patients and Interventions & Results & Comments & $\begin{array}{l}\text { Summary of } \\
\text { Results }\end{array}$ \\
\hline $\begin{array}{l}\text { Palit et al } \\
1999(83)\end{array}$ & $\mathrm{O}$ & $\begin{array}{l}38 \text { patients with nonradicular } \\
\text { neck pain underwent anterior } \\
\text { discectomy and fusion based on } \\
(+) \text { MRI or CT scan and discog- } \\
\text { raphy. All patients underwent } \\
\text { cervical discography based on } \\
\text { IASP guidelines with a concor- } \\
\text { dant disc and controlled discs. }\end{array}$ & $\begin{array}{l}\text { At mean } 53-\mathrm{mo} \mathrm{f} / \mathrm{u}, 79 \% \text { of } \\
\text { patients were satisfied with } \\
\text { outcome. }\end{array}$ & $\begin{array}{l}21 \text { patients underwent single } \\
\text { level, } 16 \text { patients two-level, } \\
\text { and one patient had a three } \\
\text { level fusion. Only five patients } \\
\text { returned to work. }\end{array}$ & $\begin{array}{l}\text { A positive evalua- } \\
\text { tion in post-MRI } \\
\text { era with evaluation } \\
\text { of the role of cervi- } \\
\text { cal discography per- } \\
\text { formed according to } \\
\text { IASP standards. }\end{array}$ \\
\hline $\begin{array}{l}\text { Zheng et al } \\
2004(50)\end{array}$ & $\mathrm{O}$ & $\begin{array}{l}55 \text { patients (161 levels) with } \\
\text { cervical discogenic pain un- } \\
\text { derwent MRI and discography. } \\
\text { Disks with abnormal MRI and } \\
\text { (+) discography underwent an- } \\
\text { terior discectomy and fusion. }\end{array}$ & $\begin{array}{l}(+) \text { discography found in } 49 \% \\
\text { of injected disks. } 63 \% \text { of dark } \\
\text { disks, } 45 \% \text { of speckled, and } \\
29 \% \text { of white disks. Discogra- } \\
\text { phy (+) in } 59 \% \text { of herniated } \\
\text { or torn disks, } 35 \% \text { of bulging, } \\
\text { and } 29 \% \text { of flat disks. } 76 \% \\
\text { of patients obtained good or } \\
\text { excellent result at mean } 3.6 \\
\text { yr f/u. }\end{array}$ & $\begin{array}{l}\text { Fusion done on } 79 \text { levels. } \\
\text { MRI findings correlated with } \\
\text { discography in } 24 \% \text { of patients } \\
\text { and } 64 \% \text { of injected levels. In } \\
79(+) \text { discograms, } 73 \% \text { had } \\
\text { abnormal MRI. In } 82 \text { levels } \\
\text { with discograms, only } 40 \text { had } \\
\text { normal MRI. }\end{array}$ & $\begin{array}{l}\text { A positive evaluation } \\
\text { in post-MRI era. } \\
\text { The combination of } \\
\text { clinical symptoms, } \\
\text { MRI, and discog- } \\
\text { raphy provides the } \\
\text { most information for } \\
\text { decision making and } \\
\text { can improve the man- } \\
\text { agement of cervical } \\
\text { discogenic pain. }\end{array}$ \\
\hline $\begin{array}{l}\text { Siebenrock } \\
\text { and Aebi } \\
1994(54)\end{array}$ & $\mathrm{O}$ & $\begin{array}{l}27 \text { patients with neck pain who } \\
\text { underwent anterior fusion and } \\
\text { discography. }\end{array}$ & $\begin{array}{l}\text { At mean } 16-\mathrm{mo} \mathrm{f} / \mathrm{u}, 73 \% \\
\text { reported good to excellent } \\
\text { results. }\end{array}$ & $\begin{array}{l}39 \text { levels fused. Included patients } \\
\text { with neurologic deficits. Patients } \\
\text { with trauma history did better } \\
\text { than those w/o trauma. }\end{array}$ & $\begin{array}{l}\text { A positive study in } \\
\text { post-MRI era. }\end{array}$ \\
\hline $\begin{array}{l}\text { Motimaya } \\
\text { et al } 2000 \\
(55)\end{array}$ & $\mathrm{O}$ & $\begin{array}{l}16 \text { patients who underwent an- } \\
\text { terior discectomy and fusion. }\end{array}$ & $\begin{array}{l}79 \% \text { of patients had good } \\
\text { to excellent results several } \\
\text { months after surgery. }\end{array}$ & $\begin{array}{l}95 \% \text { of patients had involve- } \\
\text { ment of C5-6 or C6-7. F/u } \\
\text { period, inclusion criteria, or } \\
\text { outcome measures not noted. }\end{array}$ & $\begin{array}{l}\text { A positive study in } \\
\text { post-MRI era. }\end{array}$ \\
\hline $\begin{array}{l}\text { Osler } 1987 \\
(86)\end{array}$ & $\mathrm{O}$ & $\begin{array}{l}63 \text { patients with neck pain } \\
\text { without neurological deficits } \\
\text { underwent analgesic discog- } \\
\text { raphy followed by anterior } \\
\text { discectomy and fusion. }\end{array}$ & $\begin{array}{l}81 \% \text { of the patients had excel- } \\
\text { lent or good results. All pa- } \\
\text { tients had analgesic response } \\
\text { to intradiscal } 2 \% \text { lignocaine } \\
\text { injection. }\end{array}$ & $\begin{array}{l}\text { Authors concluded that } \\
\text { analgesic discography is the } \\
\text { most effective test for location } \\
\text { of the lesion in the painful disc } \\
\text { syndrome. }\end{array}$ & $\begin{array}{l}\text { A positive study in } \\
\text { pre-MRI era. }\end{array}$ \\
\hline $\begin{array}{l}\text { Kikuchi } \\
\text { et al } 1981 \\
(56)\end{array}$ & $\mathrm{O}$ & $\begin{array}{l}138 \text { patients with cervicobra- } \\
\text { chial pain underwent disk } \\
\text { excision } \\
\text { and anterior fusion. }\end{array}$ & $\begin{array}{l}80 \% \text { of patients improved } 1-y r \\
\text { after surgery. }\end{array}$ & $\begin{array}{l}\text { Results superior to } 61 \% \text { suc- } \\
\text { cess rate in } 54 \text { patients who } \\
\text { underwent fusion without } \\
\text { discography. }\end{array}$ & $\begin{array}{l}\text { A positive study in } \\
\text { pre-MRI era. }\end{array}$ \\
\hline $\begin{array}{l}\text { White- } \\
\text { cloud and } \\
\text { Seago } 1987 \\
(24)\end{array}$ & $\mathrm{O}$ & $\begin{array}{l}40 \text { patients with neck pain and } \\
\text { no neurologic deficits under- } \\
\text { went anterior fusion based on } \\
\text { discography. }\end{array}$ & $\begin{array}{l}70 \% \text { of patients reported good } \\
\text { or excellent results at least } 12 \\
\text { months after surgery. }\end{array}$ & $\begin{array}{l}\text { All patients had } \\
\text { myelograms. } 37 \text { patients had } \\
\text { h/o trauma, six patients lost } \\
\text { to f/u. }\end{array}$ & $\begin{array}{l}\text { Positive study with } \\
70 \% \text { of patients } \\
\text { undergoing surgi- } \\
\text { cal intervention } \\
\text { reporting good or } \\
\text { excellent results. } \\
\end{array}$ \\
\hline $\begin{array}{l}\text { Hubach } \\
1994(82)\end{array}$ & $\mathrm{O}$ & $\begin{array}{l}193 \text { patients with cervical } \\
\text { radiculopathy and/or myelopa- } \\
\text { thy who underwent anterior } \\
\text { discectomy and fusion. During } \\
\text { the operation a discography was } \\
\text { performed on the symptomatic } \\
\text { level(s) and the adjacent levels. } \\
\text { All levels with positive discogra- } \\
\text { phy were fused. }\end{array}$ & $\begin{array}{l}\text { At mean } 10.4 \text { year } \mathrm{f} / \mathrm{u}, 82 \% \text { of } \\
\text { patients had good or excellent } \\
\text { results. The first } 23 \text { patients } \\
\text { underwent fusion without } \\
\text { discography. And } 35 \% \text { developed } \\
\text { adjacent segment pain. In the } 156 \\
\text { patients who had fusion based on } \\
\text { intraoperative discography, } 12 \% \\
\text { developed adjacent segment pain. }\end{array}$ & $\begin{array}{l}\text { Mean } 2.3 \text { levels fused per } \\
\text { patient. Patients were fused } \\
\text { if intraoperative discography } \\
\text { revealed abnormalities. } 14 \\
\text { patients lost to f/u. }\end{array}$ & $\begin{array}{l}\text { A positive study in } \\
\text { pre-MRI era. }\end{array}$ \\
\hline $\begin{array}{l}\text { Simmons } \\
\text { and Segil } \\
1975(81)\end{array}$ & $\mathrm{O}$ & $\begin{array}{l}56 \text { patients with cervical disk } \\
\text { disease who returned for f/u. } \\
\text { Symptomatic levels were deter- } \\
\text { mined by discography. }\end{array}$ & $\begin{array}{l}72 \% \text { of patients had good or } \\
\text { excellent results. Discography } \\
\text { was at least twice as accurate } \\
\text { as myelography, radiography, } \\
\text { or clinical exam in assessing } \\
\text { pathology. }\end{array}$ & $\begin{array}{l}58 \text { patients in series }(\mathrm{n}=114) \\
\text { lost to f/u. Inclusion criteria or } \\
\text { f/u period not noted. Diagnostic } \\
\text { accuracy of discography was } 91 \% \\
\text { compared to } 43 \% \text { for clinical } \\
\text { examination, } 46.5 \% \text { for radiogra- } \\
\text { phy, and } 45.6 \% \text { for myelography. }\end{array}$ & $\begin{array}{l}\text { A positive study in } \\
\text { pre-MRI era. }\end{array}$ \\
\hline
\end{tabular}


Table 3 cont. Characteristics of surgical outcomes.

\begin{tabular}{|c|c|c|c|c|c|}
\hline Study & $\begin{array}{l}\text { Study } \\
\text { Design }\end{array}$ & Patients and Interventions & Results & Comments & $\begin{array}{c}\text { Summary of } \\
\text { Results }\end{array}$ \\
\hline $\begin{array}{l}\text { Chirls } \\
1970(87)\end{array}$ & $\mathrm{O}$ & $\begin{array}{l}300 \text { patients with neck pain } \\
\text { and no neurologic deficits } \\
\text { underwent myelography and } \\
\text { discography. } 250 \text { had fusion } \\
\text { based on (+) discogram(s). }\end{array}$ & $\begin{array}{l}\text { Myelography was performed } \\
\text { in } 35 \% \text { of cases. } 86 \% \text { of } \\
\text { patients had good or excellent } \\
\text { results. }\end{array}$ & $\begin{array}{l}26 \text { patients had multiple levels } \\
\text { fused. Outcome measures and } \\
\text { f/u period not noted. Results } \\
\text { not noted in } 35 \% \text { of patients. }\end{array}$ & $\begin{array}{l}\text { A positive study in } \\
\text { pre-MRI era. }\end{array}$ \\
\hline $\begin{array}{l}\text { Simmons } \\
\text { et al } 1969 \\
(80)\end{array}$ & $\mathrm{O}$ & $\begin{array}{l}84 \text { patients with neck pain who } \\
\text { underwent anterior discectomy } \\
\text { and fusion. } 31 \text { patients had } \\
\text { clinical, myelographic, and } \\
\text { discographic assessment. }\end{array}$ & $\begin{array}{l}81 \% \text { obtained good or excel- } \\
\text { lent results at mean } 34-\mathrm{mo} \mathrm{f} / \mathrm{u} \text {. }\end{array}$ & $\begin{array}{l}\text { Included patients with neuro- } \\
\text { logical signs and } \\
\text { Symptoms. }\end{array}$ & $\begin{array}{l}\text { A positive study in } \\
\text { pre-MRI era. }\end{array}$ \\
\hline $\begin{array}{l}\text { Schaerer } \\
1968(79)\end{array}$ & $\mathrm{O}$ & $\begin{array}{l}247 \text { patients with neck pain } \\
\text { underwent anterior discec- } \\
\text { tomy and fusion. } 196 \text { patients } \\
\text { presented a picture of discogenic } \\
\text { pain syndrome without nerve } \\
\text { root involvement and all of them } \\
\text { underwent cervical discography. }\end{array}$ & $\begin{array}{l}76 \% \text { of patients had good } \\
\text { or excellent results. Results } \\
\text { not differentiated between } \\
\text { patients with and without } \\
\text { neurological symptoms }\end{array}$ & $\begin{array}{l}\text { All } 196 \text { patients without neu- } \\
\text { rological symptoms or trauma } \\
\text { history underwent discogra- } \\
\text { phy. F/u not noted }\end{array}$ & $\begin{array}{l}\text { A positive study in } \\
\text { pre-MRI era. }\end{array}$ \\
\hline $\begin{array}{l}\text { Roth } 1976 \\
(21)\end{array}$ & $\mathrm{O}$ & $\begin{array}{l}71 \text { patients with neck pain } \\
\text { without neurologic deficits } \\
\text { underwent anterior discectomy } \\
\text { and fusion. }\end{array}$ & $\begin{array}{l}93 \% \text { of patients had good or } \\
\text { excellent outcomes. }\end{array}$ & $\begin{array}{l}\text { All patients had analgesic re- } \\
\text { sponse to intradiscal lidocaine } \\
\text { injection, but only } 30 \% \text { had } \\
\text { concordant pain provocation. } \\
\text { F/u period not noted. }\end{array}$ & $\begin{array}{l}\text { A positive report in } \\
\text { pre-MRI era. }\end{array}$ \\
\hline $\begin{array}{l}\text { Con- } \\
\text { nor and } \\
\text { Darden } \\
1993(85)\end{array}$ & $\mathrm{O}$ & $\begin{array}{l}31 \text { patients with neck pain } \\
\text { without radicular pain un- } \\
\text { derwent cervical discography } \\
\text { followed by anterior cervical } \\
\text { discectomy and fusion. }\end{array}$ & $\begin{array}{l}\text { Of the } 22 \text { patients who under- } \\
\text { went anterior cervical discec- } \\
\text { tomy and fusion on the basis of } \\
\text { cervical discography, } 1 \text { patient } \\
\text { had an excellent result (5\%), } \\
9 \text { patients had good results } \\
\text { ( } 41 \%) \text {, and } 6 \text { patients each had } \\
\text { fair and poor results ( } 54 \%) \text {. }\end{array}$ & $\begin{array}{l}\text { Diagnostic cervical discogra- } \\
\text { phy was found not to provide } \\
\text { the degree of clinical predictive } \\
\text { value necessary to substanti- } \\
\text { ate its potential risks and } \\
\text { complications. }\end{array}$ & $\begin{array}{l}\text { Negative study of } \\
\text { cervical discog- } \\
\text { raphy in decision } \\
\text { making for anterior } \\
\text { cervical discectomy } \\
\text { and fusion in post- } \\
\text { MRI era. }\end{array}$ \\
\hline $\begin{array}{l}\text { Riley et al } \\
1969 \text { (23) }\end{array}$ & $\mathrm{O}$ & $\begin{array}{l}93 \text { patients with neck and arm } \\
\text { pain, without evidence of nerve } \\
\text { root or spinal cord compres- } \\
\text { sion, underwent anterior } \\
\text { fusion. }\end{array}$ & $\begin{array}{l}72 \% \text { of patients obtained good } \\
\text { or excellent results. Success } \\
\text { rate } 75 \% \text { for one or two-level } \\
\text { fusions and } \\
58 \% \text { for }>3 \text { levels. }\end{array}$ & $\begin{array}{l}87 \text { patients underwent discogra- } \\
\text { phy, most at time of surgery. F/u } \\
\text { period not noted. Discography } \\
\text { usually gave only confirmatory } \\
\text { diagnostic help when disc space } \\
\text { narrowing and spur formation } \\
\text { were observed on plain x-rays, } \\
\text { and when myelographic changes } \\
\text { were present. }\end{array}$ & $\begin{array}{l}\text { Discography was } \\
\text { mildly helpful in } \\
\text { pre-MRI era. }\end{array}$ \\
\hline $\begin{array}{l}\text { Klafta and } \\
\text { Collis } 1969 \\
(14)\end{array}$ & $\mathrm{O}$ & $\begin{array}{l}42 \text { patients who underwent } \\
\text { laminectomy following discog- } \\
\text { raphy and myelography. }\end{array}$ & $\begin{array}{l}\text { The accuracy of discography } \\
\text { and myelography was } 55 \% \\
\text { and } 72 \% \text {, respectively using } \\
\text { surgical findings as standard. }\end{array}$ & $\begin{array}{l}\text { Success rates were } 100 \% \text { for } \\
\text { disk protrusion, } 63 \% \text { for spon- } \\
\text { dylosis, and } 33 \% \text { in patients } \\
\text { with no pathologic findings. } \\
\text { F/u period not noted. }\end{array}$ & $\begin{array}{l}\text { The overall diagnos- } \\
\text { tic accuracy of the } \\
\text { cervical discogram } \\
\text { was only } 55 \% \\
\text { compared to the } \\
\text { diagnostic accuracy } \\
\text { of myelogram of } 72 \% \\
\text { in pre-MRI era. }\end{array}$ \\
\hline $\begin{array}{l}\text { Williams } \\
\text { et al } 1968 \\
(88)\end{array}$ & $\mathrm{O}$ & $\begin{array}{l}45 \text { patients had preoperative } \\
\text { discograms followed by ante- } \\
\text { rior cervical discectomy and } \\
\text { fusion. } 30 \text { patients underwent } \\
\text { disc excision at level of pain } \\
\text { reproduction. }\end{array}$ & $\begin{array}{l}\text { Of the } 30 \text { patients undergoing } \\
\text { disc excision at level of pain } \\
\text { reproduction, } 19 \text { reported } \\
\text { good to excellent results, } \\
\text { whereas } 4 \text { reported fair results, } \\
\text { and } 7 \text { reported poor results. }\end{array}$ & $\begin{array}{l}\text { When symptoms occur in the } \\
\text { absence of clearly defined neu- } \\
\text { rological signs, the chance of } \\
\text { a long-term good or excellent } \\
\text { result is materially reduced. } \\
\text { The value of discography and } \\
\text { myelography was not clearly } \\
\text { defined by this evaluation. }\end{array}$ & $\begin{array}{l}\text { One of the early } \\
\text { negative outcome } \\
\text { studies of cervical } \\
\text { discography fol- } \\
\text { lowed by cervical } \\
\text { discectomy and } \\
\text { interbody fusion. }\end{array}$ \\
\hline
\end{tabular}

$\mathrm{O}=$ observational

Adapted and modified from Cohen and Hurley. The ability of diagnostic spinal injections to predict surgical outcomes. Anesth Analg 2007; 105:1756-1775 (57) 
(83) evaluated outcomes in 38 patients who underwent anterior cervical discectomy and fusion for the management of non-radicular neck pain, based on discography results. Significant improvements in mean numerical rating pain scores (8.3 vs $4.1 ; P \leq 0.001)$ and Oswestry disability scores (57.5 to 38.9; $P \leq 0.001$ ) were reported, with $79 \%$ of patients being satisfied with the result. Despite improvements in pain and function, these benefits did not translate into return-to-work. This may be partly attributable to the fact that ODI scores are not validated instruments for neck pain, no differences were noted based on gender or worker's compensation status, and return-to-work tends to be more refractory to uni-dimensional therapy than other outcome measures (95).

\section{Disc Morphology and Pain Provocation}

Validity is exemplified by disc stimulation symptom mapping $(18,25)$ in pain patients and asymptomatic volunteers. Ohnmeiss et al (90) found a significant relationship between imaging and symptom provocation, with $86 \%$ of normal-looking discs either producing no pain $(60 \%)$ or atypical pain (26\%). Conversely, $78 \%$ of disrupted discs were clinically painful on injection. Viikari-Juntura et al (78) demonstrated that discography provides additional information regarding structural changes not available by any other non-invasive and non-irradiative methods of examination. In general, nuclear signal changes observed on MRI in cadavers tended to underestimate the degree of pathology appreciated with discography or gross examination. Parfenchuck and Janssen (19) found that while certain MRI patterns correlated well with positive and negative cervical discography responses, many other patterns revealed equivocal responses. They concluded that MRI is a useful adjunct to cervical discography, but that some MRI patterns should not be considered pathologic, and discography is necessary to identify a painful disc(s).

The proportion of cervical discs identified as symptomatic varies among studies. Grubb and Kelly (30) found that $50 \%$ of discs are capable of producing concordant pain upon injection. Schellhas et al (18) reported that among 11 discs that appeared normal on MRI in pain patients, 10 proved to have annular tears discographically. Two of these 10 elicited concordant pain with an intensity rating exceeding $6 / 10$. Discographically normal discs $(n=8)$ were never painful in either pain patients or an asymptomatic cohort, whereas intensely painful discs all exhibited tears of both the inner and outer annulus.
Hamasaki et al (101) retrospectively reviewed 15 cases of foraminal cervical disc herniations. Using MRI and CT-myelography, less than half of the cases were identified. In contrast, all were clearly noted on CT-discography. These findings are similar to those found by Lejeune et al (102) in a study evaluating the diagnosis and outcomes for foraminal lumbar disc herniation. The authors concluded that a majority of foraminaltype cervical disc herniations may be overlooked with conventional MRI or CT-myelography, but correctly diagnosed with $\mathrm{CT}$ discography.

Zheng et al (50) evaluated cervical discography results at 161 disc levels. There were 79 positive levels, yielding a per disc prevalence rate of $49 \%$. Fifty-nine percent of small herniated and torn discs were discographically positive. The false-positive rate of MRI was calculated to be $51 \%$ and the false-negative rate was $27 \%$. The most important criterion for determining a symptomatic disc was moderate or severe reproduction of the patient's typical pain. The presence of a control disc was not considered a diagnostic criterion in this study.

Holt's 1964 study (13) in asymptomatic prisoners reflected negatively on cervical discography. But these studies $(13,17)$ have been repeatedly refuted and better overriding data have since been generated. Holt utilized an irritant contrast and failed to employ fluoroscopic guidance. Even aside from these significant flaws, the technique itself was suspect. Extravasation of contrast material was noted with every injection, which continued even after reducing the volume. Furthermore, Holt considered "pain provocation" as being "without value."

\section{False-Positive Rates}

The main criticism regarding studies attempting to quantify false-positive discography rates is that disc stimulation in asymptomatic volunteers may not reflect pain provocation in non-painful discs in subjects with spine pain (57). Moreover, the hallmark of a positive discogram has become concordant pain provocation, which is not possible in people devoid of spine symptoms. "False" pain provocation may be produced in markedly degenerative discs in the lumbar spine, especially in the elderly $(57,103-106)$. Cohen and Larkin et al $(107,108)$ estimated that $15 \%$ to $25 \%$ of degenerative discs failed to elicit concordant pain during disc stimulation in the lumbar spine.

Overall, false-positive results with cervical provocation discography are a serious concern, with cited 
prevalence rates exceeding $50 \%$. But these rates vary as a function of the diagnostic criteria. The results of studies requiring the presence of a control disc(s) show a prevalence rate between $16 \%$ and $20 \%(31,32)$.

False-positive responses to disc stimulation can arise if the threshold for reproduction of pain is set too low. A disc is not necessarily the source of a patient's pain if the pain that is reproduced is minor or trivial. Schellhas et al (18) compared the responses to discography in asymptomatic volunteers and patients with neck pain. They found that the numerical rating pain score produced by discography in asymptomatic subjects was significantly lower $(P \leq 0.0001)$ than in patients with neck pain. Figure 2 illustrates the distribution of pain scores evoked by cervical discography in a histogram format. It was unusual for volunteers to report pain greater than 5/10 and no asymptomatic subject experienced pain exceeding 6/10. Consequently, Schellhas et al (18) recommended adding an operational criterion whereby the patient must rate the intensity of produced pain as $\geq 7$ on a 10-point numerical pain rating scale or an equivalent magnitude on another suitable scale. The emphasis then shifts from the baseline pain score to how intensely the patient rates the evoked pain. Bogduk (2) pointed out that this criterion guards against diagnosing a moderately painful disc that could nevertheless be asymptomatic. The downside of this argument is the intrinsic potential for contradictions. Theoretically, a functional patient with $10 / 10$ baseline pain could be deemed "positive" if 7/10 pain is elicited (i.e., $70 \%$ of baseline pain was provoked), whereas a disabled patient with 4/10 pain in whom disc stimulation provokes $6 / 10$ pain (i.e., $150 \%$ of baseline) would be designated as "negative."

\section{Prevalence}

Based on IASP criteria (1), the data show a prevalence rate ranging between $16 \%$ and $20 \%(31,32)$.

\section{Level of Evidence}

Based on the 3 studies that utilized IASP criteria during the performance of cervical discography $(31,32,83)$, the evidence derived from studies evaluating the diagnostic validity of the procedure indicated a Level II-2 evidence based on modified United States Preventive Services Task Force (USPSTF) criteria (66), as shown in Table 1.

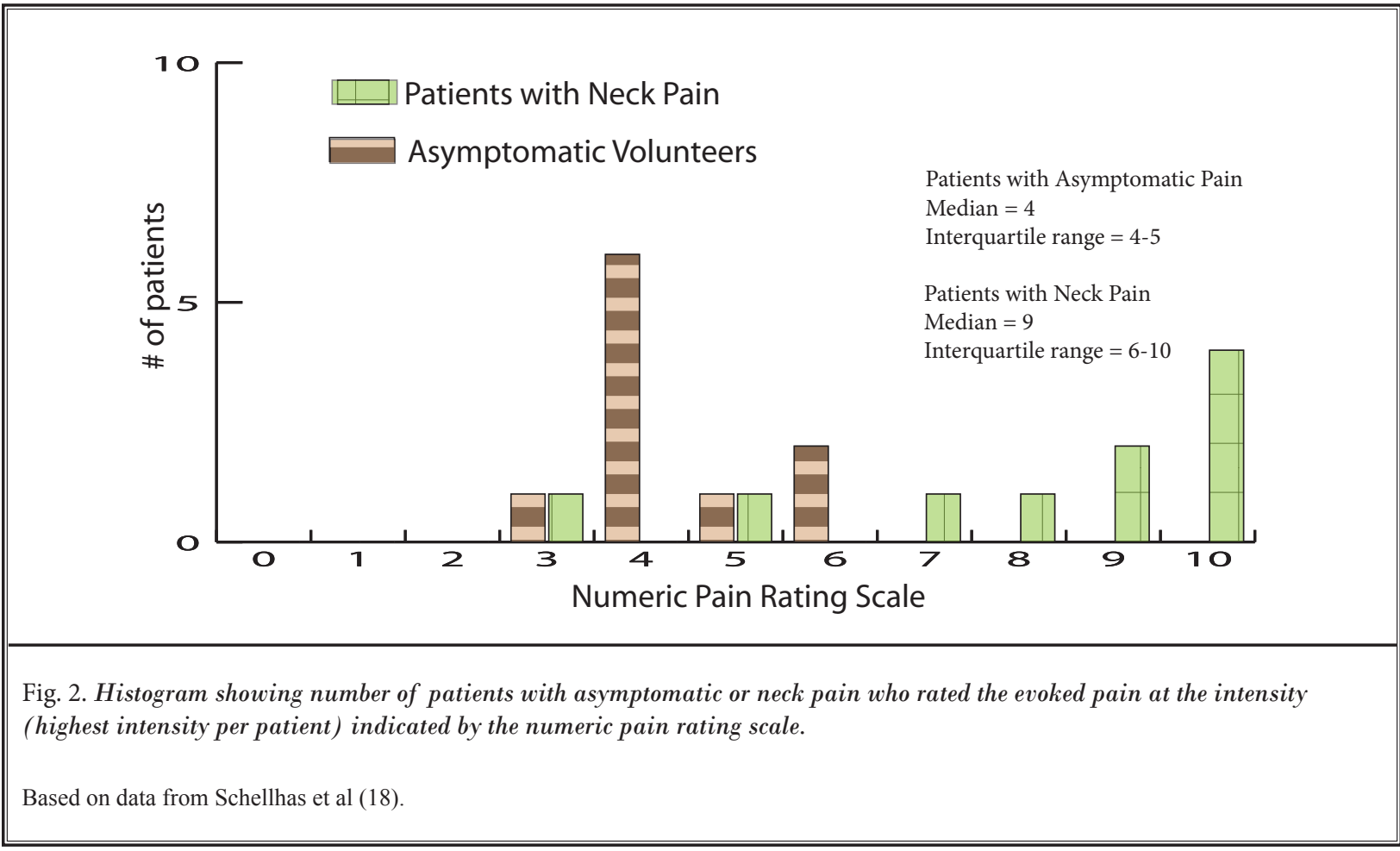




\section{Discussion}

Based on the comprehensive evaluation of all available literature, the use of cervical provocation discography in diagnosing discogenic pain was found to have moderate validity and moderate predictive value, with the indicated level of evidence being II-2. The prevalence of cervical discogenic pain was found to be between $16 \%$ and $20 \%$ based on IASP criteria $(31,32)$.

This systematic review faced significant challenges, which included the paucity of available literature and widespread discrepancies in methodology and outcome measurements. Although a significant number of studies were evaluated, only 3 studies $(31,32,83)$ utilized IASP criteria requiring a concordantly painful disc and 2 negative control discs, one above and one below the affected level.

Among the multitude of approaches described by various experts to overcome methodological biases $(76,77,79,109,110)$, the AHRQ criteria appear to be the most widespread and comprehensive. Methodological challenges encountered in this systematic review included the "gold standard" dilemma, spectrum and selection biases, subjective phenomenon of soft outcomes, observer variability, complex relations, clinical impact, small sample size, and the rapid evolution of knowledge and techniques (111). The second major criticism of discography is that disc stimulation may provoke pain in normal discs. However, the reported incidence of false-positive discography is contingent on multiple factors, including but not limited to investigator perspective (i.e., most studies that report high false-positive rates were done by spine surgeons), injection technique and needle placement, the population studied, and the criteria used to designate a discogram as "positive" (i.e., IASP or non-validated, individually developed criteria) (57). The "accepted" false-positive rates for cervical discography range from less than $5 \%$ to $27 \%$, being higher in patients with chronic neck pain than in asymptomatic subjects $(18,50,57)$. However, utilizing IASP criteria, the falsepositive rate may be reduced significantly.

The literature is replete with controversies regarding a patient's ability to accurately report pain during discography, along with multiple other potential confounding factors $(58,112-120)$. Factors besides diagnostic criteria that may influence the false-positive or false-negative rate include inappropriate patient selection, excessive or inadequate use of superficial anesthesia, needle insertion site, injection into the annulus or close to a vertebral endplate, chronological order of injection (i.e., injecting an intensely painful disc first), and insufficient or excessive sedation $(46,57,75,103,110-112,120)$. Wolfer et al $(58)$ have demonstrated that using strict validated criteria, the false-positive rate for lumbar discography is negligible $(\leq 5 \%)$ in patients without somatization disorder or failed back surgery syndrome. Although no such review has been done for cervical discography, based on the present analysis, the evidence for the validity of cervical discography indicated Level II-2.

The singular purpose of cervical discography is to identify a painful cervical intervertebral disc(s) (2). The premise upon which disc stimulation is based is that if a particular disc is painful, then stressing it under circumstances that simulate physiological conditions should reproduce the patient's pain. If the disc is not the source of a patient's pain, then stressing it either should not be painful or should produce pain that is not the patient's typical pain. Thus, disc stimulation is analogous to palpation for tenderness. Since cervical discography is a provocation test, similar to other examination tests, it is prone to false-positives results in certain circumstances.

In formal terms, disc stimulation tests the hypothesis that if a disc is the source of a patient's pain, then stressing the disc should reproduce their pain; however, simply reproducing pain cannot distinguish between a painful and non-painful disc. Thus, disc stimulation at a single segmental level does not provide a valid diagnosis. According to IASP (1), in order to maintain validity, provocation must be subjected to anatomical controls. The diagnostic criteria for discogenic pain (1) are that provocation of the target disc reproduces the patient's pain, whereas stimulation of adjacent discs does not reproduce pain.

The use of diagnostic injections to identify the source of low back pain dates back to the 1920s when von Gaza (121) used nerve blocks to illuminate obscure pain pathways. In the 1930s, Steindler and Luck (122) utilized procaine injections to identify specific pain generators in patients with chronic low back pain. In the intervening years, spinal injections have been periodically advocated as both diagnostic and prognostic screening tools before surgery, but their use in this capacity has been sporadic and inconsistent (57). An explosive growth in surgery for spinal pain and exploding costs of a multitude of interventions (61-64), a reductionist approach emphasizing precision diagnosis, together with high tech interventions (123) has 
started emerging. Yet, spinal diagnostic interventions, including cervical provocation discography continue to be controversial as screening tools for surgical intervention $(33,34,124)$. Of all the diagnostic interventions, cervical discography probably remains the most controversial, next to thoracic discography. The main criticism of cervical discography, as with any other provocation test, is that disc stimulation may provide pain in normal discs.

Shah et al (33) in their systematic and narrative review of discography as a diagnostic test for spinal pain discussed various issues starting with historical context, basic principles, lack of a gold standard, methodologic quality criteria of provocation discography, multiple assumptions about discogenic pain including pressure pain thresholds, intradiscal distention, caveats about discogenic pain, analogies, and finally, convictions. They concluded that, overall, discography is a useful imaging tool. Historically, provocation discography is the only test which has the ability to evoke pain which is unique among imaging studies. This provocative component has preserved the role of discography, but continues to generate controversy. Nonetheless, increased utilization of discography and increased physician-specialty representation among physicians performing discography suggests that discography has shed its pariah status $(61-65,124)$. In addition, the renaissance era of discography was ushered in by the concept of discogenic pain, a term synonymous with IDD. Crock (125) defined IDD as "alteration in the internal architecture of the disc, specifically excluded the escape of a disc fragment from the confines of the space (annulus)" and suggested that discography "provides the single, most valuable, special investigation in cases of disc disruption."

Basic principles of a diagnostic test are to ascertain the disease or health status in a patient. Consequently, diagnostic accuracy studies assess a diagnostic test's ability to detect the target condition. The measurements of the index test's performance are reported as statistics: sensitivity, specificity, positive and negative predictive values, positive and negative likelihood ratios, diagnostic odds ratios, and receiver operator characteristic curves. In a clinical setting where the physician doesn't know the disease status of the patient, the predictive values are relevant; the physician obtains a diagnostic test result (positive or negative) and wants to predict the truthfulness of the patient's test result $(110,126-130)$. However, the measurements are influenced by how one defines a positive or nega- tive result and the prevalence of a disease in a population (33). As a tool to evaluate pain, the sensitivity of discography can approach $100 \%$ in absolute and relative - relative to other imaging modalities - terms, depending on the definition of a negative result. If a negative disc is defined as the one that is pain free and pathology free, then a false-negative could only occur when the patient is overly sedated; there is an unrecognized equipment malfunction during the intradiscal injection; a placebo response occurs with the discography; intradiscal pathology is missed that could be detected by direct pathological inspection such as annular injection, partial nuclear filling due to the presence of a septum or intranuclear homogeneity, or lack of continuity between the nuclear cavity and the annulus (33). To develop any validity for discogenic pain, one should make certain assumptions that the disc is capable of pain generation. Consequently, discogenic pain has a structural and pathological basis that can be explained, discogenic pain can be reproduced by experimentally inducing physiological intradiscal loads, and discogenic pain may be managed. Even then, in judging the validity of provocation discography, one should not compare an unproven or poorly performed therapeutic technique.

Several authors challenged the concept that a "pain generator" can be confined to a discrete anatomic structure $(33,129-132)$. Woolf (132) has proposed that a disease or anatomic-based classification of pain be replaced with a neurobiological mechanism-based classification. Advances in pain imaging, with respect to PET scanning and functional MRI, illustrate the complexity of pain processing. In other specialties such as gastroenterology, in irritable bowel syndrome, rectal balloon distention of the sigmoid can evoke pain compared to controls, wherein pressure-evoked pain is thought to be due to altered sensory processing, either due to peripheral, spinal, or supraspinal sensitization (133). However, the increased selective attention and response is to a potentially threatening stimuli, which is a central component of sensitization (133). In this model of pain, the rectum is not the only "pain generator," per se, and one should not infer that removing or surgically treating the rectum would treat the pain. Hypothetically, a similar conceptual framework may apply to discography and discogenic pain. In fact, Giesecke et al (134) demonstrated that if equal amounts of pressure were applied to their patients, functional MRI could detect 5 common regions of neuronal activation in pain-related cortical areas in the chronic 
low back pain and fibromyalgia patients, but not the asymptomatic group. There are no readily available ways to measure the pain processes in an individual patient $(135,136)$. Consequently, despite the limitations of the structural basis of spinal pain, discography is considered to be the criterion standard for diagnosing discogenic pain. Even then, a multitude of problems persist with cervical discography with regards to optimal criteria for therapeutic management based on the diagnostic information from provocation discography. Thus, we can have many controversies and differences, but questioning the validity of discography warrants questioning the role of the intervertebral disc as a discrete pain generator, or more specifically, challenges the concept of symptomatic IDD (33).

If conducted carefully and correctly, cervical discography should be a minimal risk procedure. Connor and Darden (85) reported that the weighted mean incidence of discitis following cervical discography was 6.4 per 1,000 cases, but this was a small study in which prophylactic antibiotics were not administered. When prophylactic antibiotics were administered, the discitis risk declines to less than $0.5 \%$ per patient $(79,80,137)$. Uncontrolled increases in disc pressure may accentuate bulging discs or precipitate prolapse in already deranged cervical disc(s) (85). Cervical discography is considered hazardous in patients with spinal stenosis or disc bulges that impinge or threaten to impinge on the spinal cord (2), and may worsen or precipitate a pre-existing protrusion. Injections done at C2-3 and C7-T1 are associated with additional hazards. At C2-3, the larynx may obstruct access to the disc, whereas at C7-T1 the apex of the lung may be encountered.
Cervical discography has clinical utility if, when considered in context with radiological imaging, patient selection, and historical and physical examination findings, it provides a suggestive diagnosis of discogenic pain. This can only be achieved by performing discography utilizing IASP standards. In addition, cervical discography may have therapeutic value by preventing unnecessary surgical intervention. To summarize, there is strong evidence for the utility of cervical discography as an intervertebral disc imaging tool and that intradiscal distention can produce pain. However, the indicated level of evidence supporting the role of discography in identifying patients with chronic cervical discogenic pain is Level II-2.

Ultimately, the number of studies available with statistically significant patient numbers and consistent use of IASP standards is lacking. Larger studies with preserved investigational criterion will need to be completed.

\section{Conclusion}

Based on a modified AHRQ accuracy evaluation and USPSTF level of evidence criteria, this systematic review indicates the strength of evidence as Level II-2 for the diagnostic accuracy of cervical discography.

\section{Acknowledgments}

The authors wish to thank the editorial board of Pain Physician, for review and criticism in improving the manuscript; Vidyasagar Pampati, MSc, statistician; Sekar Edem for assistance in search of literature; and Tonie M. Hatton and Diane E. Neihoff, transcriptionists (Pain Management Center of Paducah), for their assistance in preparation of this manuscript.

\section{References}

1. Merskey H, Bogduk N. Cervical discogenic pain. In: Classification of Chronic Pain. Descriptions of Chronic Pain Syndromes and Definition of Pain Terms, 2nd ed. International Association for the Study of Pain. IASP Press, Seattle, 1994, p 108.

2. Bogduk N. Cervical disc stimulation (provocation discography). In: Practice Guidelines for Spinal Diagnostic and Treatment Procedures. ISIS, San Francisco, 2004, pp 95-111.

3. Falco FJE, Irwin L, Zhu J, Kim D, Onyewu CO. Cervical discography. In: Manchikanti L, Singh V (eds). Interventional Techniques in Chronic Spinal Pain, ASIPP Publishing, Paducah, KY, 2007, pp 567-580.
4. Singh V. The role of cervical discography in interventional pain management. Pain Physician 2004; 7:249-255.

5. Smith GW, Nichols P Jr. Technique for cervical discography. Radiology 1957; 68:718-720.

6. Smith GW. The normal cervical diskogram; with clinical observations. Am J Roentgenol Radium Ther Nucl Med 1959; 81:1006-1010.

7. Cloward RB. Cervical discography. Acta Radiol Diagn (Stockh) 1963; 1:675-688.

8. Cloward RB. Cervical diskography. A contribution to the etiology and mechanism of neck, shoulder and arm pain. Ann Surg 1959; 150:1052-1064.

9. Cloward RB. Cervical discography. Tech- nique, indications and use in the diagnosis of ruptured cervical discs. AJR 1958; 79:563-574.

10. Bogduk N, Windsor $M$, Inglis $A$. The innervation of the cervical intervertebral discs. Spine 1989; 13:2-8.

11. Groen GJ, Baljet B, Drukker J. Nerves and nerve plexuses of the human vertebral column. Am J Anat 1990; 188:282296.

12. Mendel T, Wink CS, Zimny ML. Neural elements in human cervical intervertebral discs. Spine 1992; 17:132-135.

13. Holt EP. Fallacy of cervical discography. Report of 50 cases in normal subjects. JAMA 1964; 188:799-801.

14. Klafta LA Jr., Collis JS Jr. An analysis of 
cervical discography with surgical verification. J Neurosurg 1969; 30:38-41.

15. Klafta LA Jr., Collis JS Jr. The diagnostic inaccuracy of the pain response in cervical discography. Cleve Clin Q 1969; 36:35-39.

16. Simmons JW, Aprill CN, Dwyer AP, Brodsky AE. A reassessment of Holt's data. Clin Orthop 1988; 237:120-124.

17. Holt EP. The question of lumbar dis cography. J Bone Joint Surg Am 1968; 50:720-726.

18. Schellhas KP, Smith MD, Gundry CR, Pollei SR. Cervical discogenic pain. Prospective correlation of magnetic resonance imaging and discography in as ymptomatic subjects and pain sufferers. Spine 1996; 21:300-311.

19. Parfenchuck TA, Janssen ME. A correlation of cervical magnetic resonance imaging and discography/computed tomographic discograms. Spine 1994; 19:2819-2825.

20. Oda J, Tanaka H, Tsuzuki N. Intervertebral disc changes with aging of human cervical vertebra. From the neonate to the eighties. Spine 1988; 13:1205-1211.

21. Roth DA. Cervical analgesic discography. A new test for the definitive di agnosis of the painful disc syndrome. JAMA 1976; 235:1713-1714.

22. Kofoed H. Thoracic outlet syndrome. Clin Orthop Rel Res 1981; 156:145-148.

23. Riley LH Jr, Robinson RA, Johnson KA, Walker AE. The results of anterior interbody fusion of the cervical spine. Review of 93 consecutive cases. I Neurosurg 1969; 30:127-133.

24. Whitecloud TS 3rd, Seago RA. Cervical discogenic syndrome. Results of operative intervention in patients with positive discography. Spine 1987; 2:313316.

25. Slipman CW, Plastaras C, Patel R, Isaac Z, Chow D, Garvan C, Pauza K, Furman M. Provocative cervical discography symptom mapping. Spine / 2005; 5:381-388.

26. Schellhas KP, Garvey TA, Johnson BA, Rothbart PJ, Pollei SR. Cervical diskography: Analysis of provoked responses at $\mathrm{C}_{2}-\mathrm{C}_{3}, \mathrm{C}_{3}-\mathrm{C}_{4}$, and $\mathrm{C}_{4}-\mathrm{C}_{5}$. AJNR Am J Neuroradiol 2000; 21:269-275.

27. Meyer RR. Cervical diskography. A help or hindrance in evaluating neck, shoulder, arm pain? Am J Roentgenol Radium Ther Nucl Med 1963; 90:1208-1215.

28. Sneider SE, Winslow OP Jr., Prylor TH. Cervical diskography: Is it relevant?
JAMA 1963; 185:163-165.

29. Holt EP. Further reflections on cervical discography. JAMA 1975; 231:613-614.

30. Grubb SA, Kelly CK. Cervical discography: Clinical implications from 12 years experience. Spine 2000; 25:1382-1389.

31. Bogduk N, Aprill C. On the nature of neck pain, discography and cervical zygapophysial joint blocks. Pain 1993; 54:213-217.

32. Yin W, Bogduk N. The nature of neck pain in a private pain clinic in the United States. Pain Med 2008; 9:196-203.

33. Shah RV, Everett CR, McKenzie-Brown AM, Sehgal N. Discography as a diagnostic test for spinal pain: A systematic and narrative review. Pain Physician 2005; 8:187-209.

34. Buenaventura RM, Shah RV, Patel V, Benyamin R, Singh V. Systematic review of discography as a diagnostic test for spinal pain: An update. Pain Physician 2007; 10:147-164.

35. Lotz JC, Ulrich JA. Innervation, inflammation, and hypermobility may characterize pathologic disc degeneration: Review of animal model data. J Bone Joint Surg Am 2006; 88:76-82.

36. Cavanaugh JM, Lu Y, Chen C, Kallakuri S. Pain generation in lumbar and cervical facet joints. J Bone Joint Surg Am 2006; 88:63-67.

37. Windsor RE, Nagula D, Storm S. Electrical stimulation induced cervical medial branch referral patterns. Pain Physician 2003; 6:411-418.

38. Fukui S, Ohseto K, Shiotani M, Ohno K, Karasawa H, Naganuma Y, Yuda Y. Referred pain distribution of the cervical zygapophyseal joints and cervical dorsal rami. Pain 1996; 68:79-83.

39. Dwyer A, Aprill C, Bogduk N. Cervical zygapophyseal joint pain patterns. I: A study in normal volunteers. Spine 1990; 15:453-457.

40. Cooper G, Bailey B, Bogduk N. Cervical zygapophysial joint pain maps. Pain Med (USA) 2007; 8:344-353.

41. Lord SM, Barnsley L, Wallis BJ, Bogduk N. Chronic cervical zygapophysial joint pain with whiplash: A placebo-controlled prevalence study. Spine 1996; 21:1737-1745.

42. Manchukonda R, Manchikanti KN, Cash KA, Pampati V, Manchikanti L. Facet joint pain in chronic spinal pain: An evaluation of prevalence and false-positive rate of diagnostic blocks. I Spinal Disord Tech 2007; 20:539-545.
43. Manchikanti L, Boswell MV, Singh V, Pampati V, Damron KS, Beyer CD. Prevalence of facet joint pain in chronic spinal pain of cervical, thoracic, and lumbar regions. BMC Musculoskelet Disord 2004; 5:15.

44. Manchikanti L, Manchikanti K, Cash KA, Singh V, Giordano J. Age-related prevalence of facet joint involvement in chronic neck and low back pain. Pain Physician 2008; 11:67-75.

45. Manchikanti L, Manchikanti KN, Pampati V, Brandon DE, Giordano J. The prevalence of facet-joint-related chronic neck pain in postsurgical and nonpostsurgical patients: A comparative evaluation. Pain Pract 2008; 8:5-10.

46. Manchikanti L, Cash KA, Pampati V, Fellows B. Influence of psychological variables on the diagnosis of facet joint involvement in chronic spinal pain. Pain Physician 2008; 11:145-160.

47. Barnsley L, Lord SM, Wallis BJ, Bogduk $N$. The prevalence of chronic cervical zygapophyseal joint pain after whiplash. Spine 1995; 20:20-26.

48. Manchikanti L, Singh V, Rivera J, Pampati V. Prevalence of cervical facet joint pain in chronic neck pain. Pain Physician 2002; 5:243-249.

49. Stuck RM. Cervical discography. Am J Roentgenol Radium Ther Nucl Med 1961; 86:975-982.

50. Zheng Y, Liew SM, Simmons ED. Value of magnetic resonance imaging and discography in determining the level of cervical discectomy and fusion. Spine 2004; 29:2140-2145.

51. Sohn HM, You JW, Lee JY. The relationship between disc degeneration and morphologic changes in the intervertebral foramen of the cervical spine: A cadaveric MRI and CT study. J Korean Med Sci 2004; 19:101-106.

52. Ernst CW, Stadnik TW, Peeters E, Breucq C, Osteaux MJ. Prevalence of annular tears and disc herniations on MR images of the cervical spine in symptom free volunteers. Eur J Radiol 2005; 55:409414.

53. Dai L. Disc degeneration and cervical instability. Correlation of magnetic resonance imaging with radiography. Spine 1998; 23:1734-1738.

54. Siebenrock KA, Aebi M. Cervical discography in discogenic pain syndrome and its predictive value for cervical fusion. Arch Orthop Trauma Surg 1994; 113:199-203.

55. Motimaya A, Arici M, George D, Rams- 
by $G$. Diagnostic value of cervical discography in the management of cervical discogenic pain. Conn Med 2000; 64:395-398.

56. Kikuchi S, Macnab I, Moreau P. Localisation of the level of symptomatic cervical disc degeneration. J Bone Joint Surg Br 1981; 63-B:272-277.

57. Cohen SP, Hurley RW. The ability of diagnostic spinal injections to predict surgical outcomes. Anesth Analg 2007; 105:1756-1775.

58. Wolfer L, Derby R, Lee JE, Lee SH. Systematic review of lumbar provocation discography in asymptomatic subjects with a meta-analysis of false-positive rates. Pain Physician 2008; 11:513538.

59. Schoelles K, Reston J, Treadwell J, Noble M, Snyder D. Spinal fusion and discography for chronic low back and uncomplicated lumbar degenerative disc disease. Health Technology Assessment. Washington State Health Care Authority; October 19, 2007.

6o. Manchikanti L, Singh V, Derby R, Schultz DM, Benyamin RM, Prager JP, Hirsch JA. Reassessment of evidence synthesis of occupational medicine practice guidelines for interventional pain management. Pain Physician 2008; 11:393482.

61. Manchikanti L, Boswell MV. Interventional techniques in ambulatory surgical centers: A look at the new payment system. Pain Physician 2007; 10:627650.

62. Manchikanti L, Giordano J. Physician payment 2008 for interventionalists: Current state of health care policy. Pain Physician 2007; 10:607-626.

63. Manchikanti L, Singh V, Pampati V, Smith HS, Hirsch J. Analysis of growth in interventional techniques in managing chronic pain in Medicare population: A 10-year evaluation from 1997 to 2006. Pain Physician 2009; 12:9-34.

64. Manchikanti L. Health care reform in the United States: Radical surgery needed now more than ever. Pain Physician 2008; 11:13-42.

65. Specialty Utilization data files from CMS: www.cms.hhs.gov.

66. Berg AO, Allan JD. Introducing the third U.S. Preventive Services Task Force. Am J Prev Med 2001; 20:S3-S4.

67. West S, King V, Carey TS, Lohr KN, McKoy N, Sutton SF, Lux L. Systems to Rate the Strength of Scientific Evidence, Evidence Report, Technology Assess- ment No. 47. AHRQ Publication No. 02E016. Rockville, MD: Agency for Healthcare Research and Quality, 2002. www. thecre.com/pdf/ahrq-system-strength. pdf

68. Bossuyt PM, Reitsma JB, Bruns DE, Gatsonis CA, Glasziou PP, Irwig LM, Lijmer JG, Moher D, Rennie D, de Vet HC; Standards for Reporting of Diagnostic Accuracy. Towards complete and accurate reporting of studies of diagnostic accuracy: The STARD initiative. Clin Chem 2003; 49:1-6.

69. Atluri S, Datta S, Falco FJ, Lee M. Systematic review of diagnostic utility and therapeutic effectiveness of thoracic facet joint interventions. Pain Physician 2008; 11:611-629.

70. Singh V, Manchikanti L, Shah RV, Dunbar EE, Glaser SE. Systematic review of thoracic discography as a diagnostic test for chronic spinal pain. Pain Physician 2008; 11:631-642.

71. Carragee EJ. Hannibal M. Diagnostic evaluation of low back pain. Orthop Clin North Am 2004; 35:7-16.

72. Falco FJE, Erhart S, Wargo BW, Bryce DA, Atluri S, Datta S, Hayek SM. Systematic Review of Diagnostic Utility and Therapeutic Effectiveness of Cervical Facet Joint Interventions. Pain Physician 2009; 12:323-344.

73. Falco FJE, Erhart S, Wargo BW, Bryce DA, Atluri S, Datta S, Hayek SM. Systematic Review of Diagnostic Utility and Therapeutic Effectiveness of Cervical Facet Joint Interventions. Pain Physician 2009; 12:323-344.

74. Rupert MP, Lee M, Manchikanti L, Datta S, Cohen SP. Evaluation of Sacroiliac Joint Interventions: A Systematic Appraisal of the Literature. Pain Physician 2009; 12:399-418.

75. Smith HS, Chopra P, Patel VB, Frey ME, Rastogi R. Systematic review on the role of sedation in diagnostic spinal interventional techniques. Pain Physician 2009; 12:195-206.

76. Lijmer JG, Mol BW, Heisterkamp S, Bonsel GJ, Prins $M H$, van der Meulen JH, Bossuyt PM. Empirical evidence of design-related bias in studies of diagnostic tests. JAMA 1999; 282:1061-1066.

77. Reid MC, Lachs MS, Feinstein AR. Use of methodological standards in diagnostic test research. Getting better but still not good. JAMA 1995; 274:645 651.

78. Viikari-Juntura E, Raininko R, Videman T, Porkka L. Evaluation of cervical disc degeneration with ultralow field MRI and discography: An experimental study on cadavers. Spine 1989; 14:616619.

79. Schaerer JP. Anterior cervical disc removal and fusion. Schweiz Arch Neurol Neurochir Psychiatr 1968; 102:331344 .

80. Simmons EH, Bhalla SK, Butt WP. Anterior cervical discectomy and fusion: A clinical and biomechanical study with eight year follow up with a note on discography technique and interpretation of results. J Bone Joint Surg 1969; 51B:225-237.

81. Simmons EH, Segil CM. An evaluation of discography in the localization of symptomatic levels in discogenic disease of the spine. Clin Orthop Relat Res 1975; 108:57-69.

82. Hubach PC. A prospective study of anterior cervical spondylodesis in intervertebral disc disorders. Eur Spine J 1994; 3:209-213.

83. Palit M, Schofferman J, Goldthwaite N, Reynolds J, Kerner M, Keaney D, Lawrence-Miyasaki L. Anterior discectomy and fusion for the management of neck pain. Spine 1999; 24:2224-2228.

84. Shinomiya K, Nakako K, Mochida K, Furuya K. Evaluation of cervical diskography in pain origin and provocation. J Spinal Disord 1993; 6:422-426.

85. Connor PM, Darden BV II. Cervical discography complications and clinical efficacy. Spine 1993; 18:2035-2038.

86. Osler GE. Cervical analgesic discography. A test for diagnosis of the painful disc syndrome. S Afr Med J 1987; 71:363.

87. Chirls M. Discography, myelography, and interbody fusions for cervical syndromes. J Med Soc N J 1970; 67:530532.

88. Williams JL, Allen MB, Harkess JW. Late results of cervical discectomy and interbody fusion: Some factors influencing the results. J Bone Joint Surg Am 1968; 50:277-286.

89. Menkowitz M, Stieber JR, Wenokor C, Cohen JD, Donald GD, Cresanti-Dakinis C. Intradiscal pressure monitoring in the cervical spine. Pain Physician 2005; 8:163-166.

90. Ohnmeiss DD, Guyer RD, Mason SL. The relation between cervical discographic pain responses and radiographic images. Clin J Pain 2000; 16:1-5.

91. Slipman CW, Plastaras CT, Palmitier RA, Huston CW, Sterenfeld EB. Symptom 
provocation of fluoroscopically guided cervical nerve root stimulation. Are dynatomal maps identical to dermatomal maps? Spine 1998; 23:2235-2242.

92. Barnsley L, Lord SM, Wallis BJ, Bogduk N. False-positive rates of cervical zygapophysial joint blocks. Clin J Pain 1993; 9:124-130.

93. Deyo RA, Nachemson A, Mirza SK. Spinal-fusion surgery - The case for restraint. N Engl J Med 2004; 350:722726.

94. Jacobs WC, Anderson PG, Limbeek J, Willems PC, Pavlov P. Single or doublelevel anterior interbody fusion techniques for cervical degenerative disc disease. Cochrane Database Syst Rev 2004;18:CDo04958.

95. Zampolini M, Bernardinello M, Tesio L. RTW in back conditions. Disabil Rehabil 2007; 29:1377-1385.

96. Heiskari M. Comparative retrospective study of patients operated for cervical disc herniation and spondylosis. Ann Clin Res 1986; 18:57-63.

97. Martins AN. Anterior cervical discectomy with and without interbody bone graft. J Neurosurg 1976; 44:290-295.

98. Colhoun E, McCall IW, Williams L, Cassar Pullicino VN. Provocation discography as a guide to planning operations on the spine. J Bone Joint Surg Br 1988; 70:267-271.

99. Esperson JO, Buhl M, Eriksen EF, Fode K, Klaerke A, Krøyer L, Lindeberg H, Madsen CB, Strange P, Wohlert L. Treatment of cervical disc disease using Cloward's technique: General results, effect of different operative methods and complications in 1106 patients. Acta Neurochirurg 1984; 70:97-114.

100. Hirsh LF. Cervical degenerative arthritis: Possible cause of neck and arm pain. Postgrad Med 1983; 74:123-130.

101. Hamasaki T, Baba I, Tanaka S, Sumida T, Manabe H, Tanaka N, Ochi M. Clinical characterizations and radiologic findings of pure foraminal-type cervical disc herniation: CT discography as a useful adjuvant in its precise diagnosis. Spine 2005; 30:E591-E596.

102. Lejeune JP, Hladky JP, Cotten A, Vinchon M, Christiaens JL. Foraminal lumbar disc herniation. Experience with 83 patients. Spine 1994; 19:1905-1908.

103. Vanharanta H, Guyer RD, Ohnmeiss DD, Stith WJ, Sachs BL, Aprill C, Spivey M, Rashbaum RF, Hochschuler SH, Videman T, Selby DK, Terry A, Mooney V. Disc deterioration in low back syn- dromes. A prospective, multi-center $\mathrm{CT} /$ discography study. Spine 1988; 13:1349-1351.

104. Vanharanta H, Sachs BL, Ohnmeiss DD, Aprill C, Spivey M, Guyer RD, Rashbaum RF, Hochschuler SH, Stith WJ, Mooney V. Pain provocation and disc deterioration by age. A CT/discography study in a low-back pain population. Spine 1989; 14:420-423.

105. Moneta GB, Videman T, Kaivanto K, Aprill C, Spivey M, Vanharanta H, Sachs BL, Guyer RD, Hochschuler SH, Raschbaum RF, Mooney V. Reported pain during lumbar discography as a function of anular ruptures and disc degeneration. Spine 1994; 19:1968-1974.

106. Maezawa S, Muro T. Pain provocation at lumbar discography as analyzed by computed tomography/discography. Spine 1992; 17:1309-1315.

107. Cohen SP, Larkin TM, Barna SA, Palmer WE, Hecht AC, Stojanovic MP. Lumbar discography: A comprehensive review of outcome studies, diagnostic accuracy, and principles. Reg Anesth Pain Med 2005; 30:163-183.

108. Cohen SP, Larkin TM. Lumbar discography. In: Benzon HT, Rathmell JP, Wu CL, Turk DC, Argoff CE (eds). Raj's Practical Management of Pain. 4th ed. Elsevier Science, Philadelphia 2008, pp 10791108.

109. Whiting P, Rutjes A, Reitsma J, Bossuyt P, Kleijnen J. The development of QUADAS: A tool for the quality assessment of studies of diagnostic accuracy included in systematic reviews. $B M C$ Med Res Methodol 2003; 3:25.

110. Deeks JJ. Systematic reviews in health care: Systematic reviews of evaluations of diagnostic and screening tests. BMJ 2001; 323:157-162.

111. Knottnerus JA, van Weel C, Muris JW. Evaluation of diagnostic procedures. BMJ 2002; 324:477-480.

112. Saal JS. General principles of diagnostic testing as related to painful lumbar spine disorders. Spine 2002; 27:25382545.

113. Derby R, Lee SH, Kim BJ, Chen Y, Aprill C, Bogduk N. Pressure-controlled lumbar discography in volunteers without low back symptoms. Pain Med 2005; 6:213-221.

114. Carragee EJ, Chen Y, Tanner CM, Hayward C, Rossi M, Hagle C. Can discography cause long-term back symptoms in previously asymptomatic subjects? Spine 2000; 25:1803-1808.
115. Carragee EJ, Barcohana B, Alamin T, van den Haak E. Prospective controlled study of the development of lower back pain in previously asymptomatic subjects undergoing experimental discography. Spine 2004; 29:1112-1117.

116. Derby R. Lumbar discometry. Newsletter of International Spine Injection Society 1993; 1:8-17.

117. Derby R, Howard MW, Grant JM, Lettice JJ, Van Peteghem PK, Ryan DP. The ability of pressure-controlled discography to predict surgical and nonsurgical outcomes. Spine 1999; 24:364-371.

118. Shin D, Kim H, Jung J, Sin D, Lee J. Diagnostic relevance of pressure-controlled discography. J Korean Med Sci 2006; 21:911-916.

119. Manchikanti L, Singh V, Pampati VS, Fellows B, Beyer C, Damron K, Cash KA. Provocative discography in low back pain patients with or without somatization disorder: A randomized prospective evaluation. Pain Physician 2001; 4:227-239.

120. Cohen SP, Oberfell R, Larkin T, Fant, G, Stojanovic M. Does needle insertion site affect discography results? A retrospective analysis. Spine 2002; 27: 2279-2283.

121. von Gaza W. Die Resektion der paravertebralen Nerven und die isolierte Durchschneidung des Ramus communicans. Arch Klin Chir 1924; 133:479.

122. Steindler A, Luck JV. Differential diagnosis of pain in the low back: Allocation of the source of the pain by the procaine hydrochloride method. JAMA 1938; 110:106-113.

123. Bogduk N, McGuirk B. Treatment strategies. In: Medical Management of Acute and Chronic Low Back Pain. An Evidence-based Approach Pain Research and Clinical Management. Vol 13. Elsevier Science, Amsterdam, 2002, pp 177-186.

124. Boswell MV, Trescot AM, Datta S, Schultz DM, Hansen HC, Abdi S, Sehgal N, Shah RV, Singh V, Benyamin RM, Patel VB, Buenaventura RM, Colson JD, Cordner HJ, Epter RS, Jasper JF, Dunbar EE, Atluri SL, Bowman RC, Deer TR, Swicegood JR, Staats PS, Smith HS, Burton AW, Kloth DS, Giordano J, Manchikanti L. Interventional techniques: Evidencebased practice guidelines in the management of chronic spinal pain. Pain Physician 2007; 10:7-111.

125. Crock HV. A reappraisal of intervertebral disc lesions. Med J Aust 1970; 1:983-989. 
126. Wassertheil-Smoller S. Mostly about screening. In: Wassertheil-Smoller S (ed). Biostatistics and Epidemiology $A$ Primer for Health and Biomedical Professionals. Springer-Verlag, New York, 2004, pp 129-140.

127. Weinstein S, Obuchowski NA, Lieber ML. Clinical evaluation of diagnostic tests. AJR Am J Roentgenol 2005; 184:14-19.

128. Riegelman RK. Testing a test (Section II). In: Riegelmann RK (ed). Studying a Study and Testing a Test: How to Read the Medical Evidence, 5th ed. Lippincott Williams \& Wilkins, Philadelphia, 2005, pp 137-192.

129. Melzack R. From the gate to the neuromatrix. Pain 1999; 6:S121-S126.

130. Devor M. Unexplained peculiarities of the dorsal root ganglion. Pain 1999; 6: S27-S35.

131. Carragee EJ, Alamin TF, Miller J, Grafe M. Provocative discography in volunteer subjects with mild persistent low back pain. Spine J 2002; 2:25-34.

132. Woolf CJ, American College of Physicians, American Physiological Society. Pain: moving from symptom control toward mechanism-specific pharmacologic management. Ann Intern Med 2004; 140:441-451.

133. Wilder-Smith $\mathrm{CH}$, Schindler D, Lovblad K, Redmond SM, Nirkko A. Brain functional magnetic resonance imaging of rectal pain and activation of endogenous inhibitory mechanisms in irritable bowel syndrome patient subgroups and healthy controls. Gut 2004;
53:1595-1601.

134. Giesecke T, Gracely RH, Grant MA, Nachemson A, Petzke F, Williams DA, Clauw DJ. Evidence of augmented central pain processing in idiopathic chronic low back pain. Arthritis Rheum 2004; 50:613-623.

135. Hansson PT, Dickenson AH. Pharmacological treatment of peripheral neuropathic pain conditions based on shared commonalities despite multiple etiologies. Pain 2005; 113:251-254.

136. Hansson P. Difficulties in stratifying neuropathic pain by mechanisms. Eur J Pain 2003; 7:353-357.

137. Vogelsang H. Discitis intervertebralis cervicalis nack diskographie. Neurochirurgia 1973; 16:80-83. 
